Volume 9, No.1, January - February 2020

International Journal of Advanced Trends in Computer Science and Engineering

Available Online at http://www.warse.org/IJATCSE/static/pdf/file/ijatcse63912020.pdf

https://doi.org/10.30534/ijatcse/2020/63912020

\title{
Developing Management of Quran Memorization Institutions through the Web System
}

\author{
Tedi Priatna ${ }^{1}$, Nurhamzah ${ }^{2}$, Yaya Suryana ${ }^{3}$, Nano Nurdiansah ${ }^{4}$ \\ ${ }^{1}$ UIN Sunan Gunung Djati Bandung, Indonesia, tedi.priatna@uinsgd.ac.id \\ ${ }^{2}$ UIN Sunan Gunung Djati Bandung, Indonesia, nurhamzah@uinsgd.ac.id \\ ${ }^{3}$ UIN Sunan Gunung Djati Bandung, Indonesia, yayasuryana@uinsgd.ac.id \\ ${ }^{4}$ STKIP Sebelas April Sumedang, Indonesia, nano.nurdiansah@gmail.com
}

\begin{abstract}
The role of technology in life has become a necessity for every user, including the use of technology in the management of Quran memorization. The purpose of this study is to develop memorization of the Quran through a web system. This study uses a case study method in Quran memorizing institutions Maulana Malik Ibrahim State Islamic University Malang Indonesia. The results of the study show that the use of the web in managing Quran memorization has provided various facilities for the managers and their members. The web is used in a variety of Quran memorization activities ranging from student registration announcements, notification of selection test schedules, announcement of the results of completion tests, distribution of Quran memorization groups, final memorization tests, as well as appreciation activities to students who have mastered Quran memorization. With the use of the web, Quran memorization management becomes easier so students can access various activities wherever they are.
\end{abstract}

Key words: Management Technology, Technology, Quran memorization, Web system, Website

\section{INTRODUCTION}

For three decades technology (the internet) has become a way of carrying out one's worship [1], however, this has not been used in religious education, for years the use of technology in the process of teaching Islamic education has been ignored [2]. In fact, at the present time the development of technology has become a culture in society, the advancement of science and technology has resulted in changes in many aspects of the social and moral order [3], the relationship between technology, religion and environment has become the most important thing in human life [4]. As the importance of technology in everyday life, technology also has a very important role and influence with education in the field of teaching [5]. Therefore, as technology develops, several studies related to the use of technology in religious education have developed rapidly. Tahereh revealed in his research that technology has become the key to educational success [6]. $n$ the next study, it was explained that the integration of religious education with science and technology would be able to restore education to its original goal of knowing, understanding, contemplating, believing, being virtuous, and having a noble character in applying Islamic teachings from the main sources of Quran and Al- Hadith [7]. In addition, learning religious education will be more able to attract students' attention if the teacher uses multimedia in the learning process [8]. The use of technology has also become a learning model that is practical in nature, so that it will be able to improve processes and results through a learning environment created with the use of technology [9]. some of the previous studies are examples related to the use of technology in the field of religious education. However, if we explore further that studies related to the use of technology in managing Quran memorization, research is still rare. In other studies, technology has been used in distance learning rather than classroom learning, making students more than traditional learning in the classroom [10]. Thus, the focus of this research is the use of web-based technology in the management of Quran memorization, so that it is expected that after this research will be carried out it will be able to make the technology of the web as a management process in memorizing the Quran. Where with web-based technology, moreover today web service technology become popular [11]-[13], can help memorizing the Quran more easily. Then further, the wisdom in using technology as a tool for memorizing the Quran will be able to direct change better [14].

\section{METHODS}

This study uses Waterfall methodology as Software Development Life Cycle to build the web system. The Waterfall method begin from requirement elicitation [15], analysis, design, implementation, testing, deployment, until maintenance [16], [17]. This method is selected because the requirements has been completed and clearly defined. 
For user acceptance test, this study uses a survey method of 30 students of Malang Maulana Malik Ibrahim State Islamic University who have graduated and are entitled to take part in Quran memorization school. The 30 students consisted of 20 female students and 10 male students, the collection technique was done by distributing questionnaires to students who were status as Quran memorizing school participants. In addition, to complete the data in this study, interviews were also conducted with 5 Quran memorization instructors related to the use of the web in managing Quran memorization of students, and the last was data collection techniques in the form of documents used in the memorization process of $\mathrm{Al}$ -Quran.

\section{RESULT AND DISCUSSION}

Quran memorization has become one of the flagship programs of Malang's Maulana Malik Ibrahim UIN under a coaching institution called Ha'iah Tahfizh Al-Qur'an (HTQ). The Ha'iah Tahfizh Al-Qur'an Institute (HTQ) has been established since 2012 and until now it has had 200 A-Quran memorizing santri from various study programs in the Maulana Malik Ibrahim State Islamic University. As a superior institution, this institution is also supported by infrastructure facilities specifically used for students of the Quran memorizers, these suggestions have made students more enthusiastic in memorizing the Quran.

The Ha'iah-Tahfizh Al-Qur'an Institute (HTQ) is increasingly grounded and is widely known after the institution uses the web as one of the media technologies used by institutions in managing student Quran memorization. The web feature that is used is a feature that is simple, albeit simple, the use of the web has made this institution make a major change to keep up with technological developments by using it in the management of Quran memorization. The Ha'iah Tahfizh Al-Qur'an Institute (HTQ) requires all prospective students to always monitor and interact with their web as a way to familiarize students with using technology in the process and stages of memorizing the Quran. The stages that must be done by new students who will register as students of the Qurana memorization must first log in, then the system will process and notify the entered data (valid or invalid). When the data entered is invalid, the system will confirm the user and if the data entered is valid, the system will process and receive the data entered.

After students are registered, then they will receive an announcement of the entrance test schedule to categorize memorization and divide the guidance group memorizing the Quran and students can access the announcement via the web. For new students the Quran test is very important, the results of the test will be used by the committee to make a guidance group to memorize the Quran. Among them there are those who have to enter first guidance to improve their reading, as there are also those who enter the group who have memorized 2 Juz, and also part of the group that has memorized as many as 5 juz Quran. In the next stage the web is used by managers for students who will carry out the memorization test of the Quran. For those who will carry out the memorization test of the Quran, they must first register as examinees via the web, then they can see the announcement regarding the schedule for conducting the exam via the web. For participants who pass the exam, they are entitled to register as participants in Quran memorization graduation. This graduation process is usually held once a year during a general meeting between the University and parents of new students. This concept was built in the hope that there would be an interest from parents to mobilize their children to attend the school of memorizing the Quran located in Malang's Maulana Malik Ibrahim State Islamic University. If made in a scheme, then in general the scheme of Quran rote management system in Ha'iah Tahhizh Al-Qur'an (HTQ) using the web system as follows.

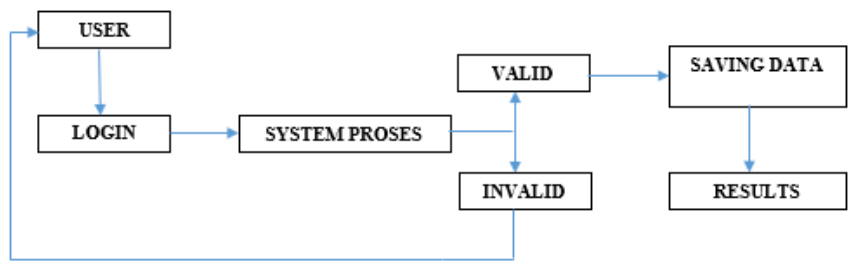

Figure 1: Scheme of Quran Memorization Web System

In addition to memorizing Quran activities, the web is also used for other activities related to Quran activities. On the web, Taaruf Quran features are presented. Taaruf Quran is a motivational gift and briefing related to the Quran. The Taaruf Quran feature is one of the offerings for new students who are memorizing Quran candidates, their offerings include applicants for new students and the announcement of the results of the selection of new students memorizing the Quran. In this activity, students will be introduced more closely to Quran, so that after participating in the activity students will be more motivated to become more familiar with the Quran.

In addition, other features contained in the web are Assyahrul Quran. Assyahrul Quran is an Quran camp activity for a full month to memorize the Quran. This activity can be carried out on semester holidays, so that there are two Quran camp activities in one year. In these activities the participants are not only students but students from junior high school, high school, and students outside the Maulana Malik Ibrahim State Islamic University. In this activity the students were trained for a full month to memorize the Quran with the time determined by the committee. Apart from memorizing the Quran, activities are also filled with scientific studies related to the Quran. As an entertainment activity, the committee prepared outbound activities as a form of refreshing exercise and eliminated boredom after memorizing the Quran continuously. 


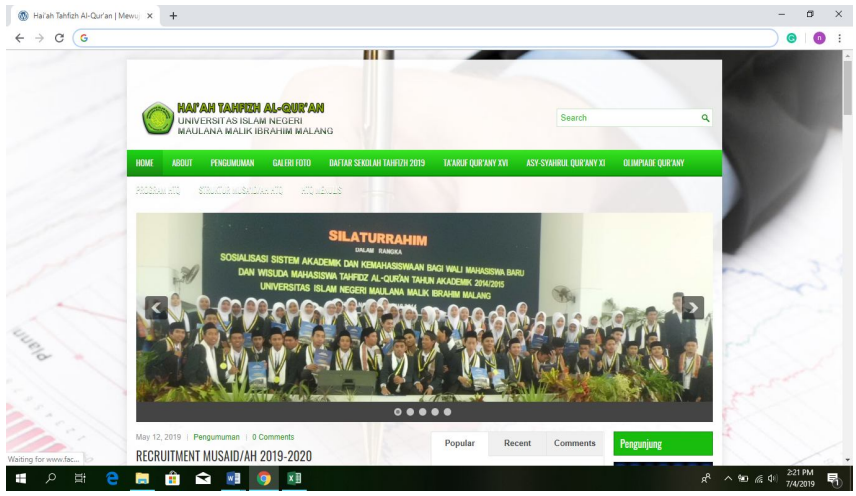

Figure 2: Implementation of Web Ha'iah Tahfizh Al-Qur'an (HTQ)

The above is a picture of a webset in which there are several features related to student activities in memorizing the Quran, features - these features help students to memorize the Quran more effectively. Feature announcement is one feature that provides information to all memorizers of the Quran related to registration of memorization companions, announcement of test results, and graduation registration for those who have completed their memorandum. Furthermore, the feature presented is the feature of registration for new students who want to take part in the Quran memorization program, prospective students will immediately register online on the web. The next feature is ta'ufuf qurany, this feature is a presentation related to acceptance as a member of the Ha'ah Tahfizh Quran (HTQ) which will help tutors in fostering the memorizers of the Quran. Another feature presented is the presentation of information regarding the implementation of the quarantine program for memorizers of the Quran. The ash-syahrul qurany program is followed not only by local students, but registration is open to the public for all students / students who want to memorize the Quran. The last feature presented is the Olympic Qurany, which contains information about the race - a special race in the field of the Quran, including the race to read the Quran, the memorizing race of the Quran, and the Quran quiz competition. Through features - these features all students must open and register directly in private in the available column. Through this activity, all activities related to Quran memorization management are carried out online through the Ha'iah Tahfizh Al-Qur'an (HTQ) web. The following are the results of surveys related to web use in the management of Quran memorization.

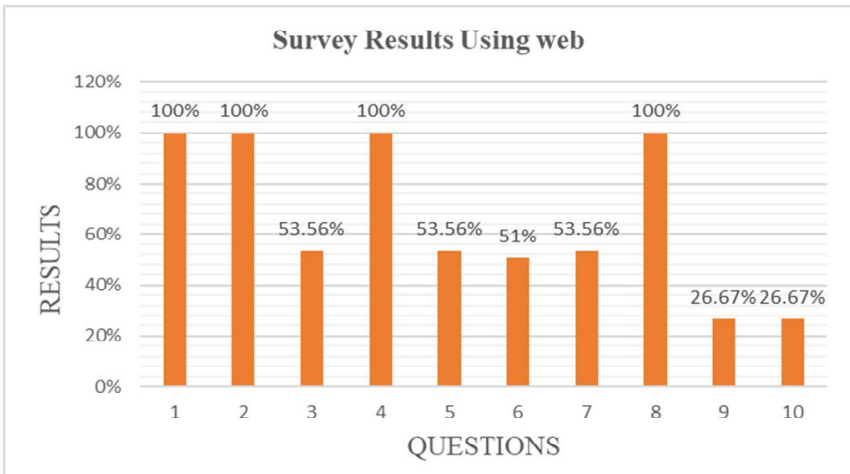

Figure 3: User Acceptance Result using Survey
From the results of the survey data it was found that the questions number 1, 2, 3, and 4 were activities carried out by all participants of the Quran memorizer. This explains that as many as 30 participants entered into a login activity, registering as prospective Quran memorized students, selection lists, graduation test lists. this shows that student enthusiasm is very high when doing the process as much as $100 \%$. Meanwhile, the score obtained at the next stage is above $50 \%$. activities - these activities are activities that are not directly acceptable to the information by students or students get the same information with other themes, so they do not have to open or use the web to find out. These activities include the announcement of the results of the tests, the announcement of the distribution of rote groups, the announcement of rote schedules and tutors, and the announcement of the schedule for graduation for those who have passed the memorization test. In the third part, students who memorize the Quran rarely use the web when activities to obtain information on the development and memorization of the Quran and they rarely use the web for activities other than directly related to memorizing the Quran.

The development of technology has provided a new nuance in the field of education, the results of the study prove that in the era of technology, Quran memorization has also been integrated into a technology system called the web. In Islam all useful new developments in the field of science and cultural achievement must be adopted [5] including the integration of technology in religious education. The use of technology in the field of education has been able to provide new colors as facilitators for tutors and students, so that technology in managing Quran memorization makes it easier for students as well as tutors who monitor and supervise the memorization of all their students.

The use of the web in managing Quran memorization is a concept of technology utilization that is full of values and ethics, students cannot use the web carelessly with things that are not easy and beyond their needs. They only use the web for their needs as memorizing members of the Quran. In the use of technology Islamic ethics is a system of ethics formed by the teachings of the Quran and explained by the Prophet Muhammad through actions and words. Islamic ethics deals with standards that determine what Muslims should do. It also gives a value of virtue, duties, attitudes of individuals and society [18]. The use of technology has also made the memorizers of the Quran more contextual by understanding the concepts of life and development through technology, this is a real educational goal, namely education has been able to foster social [19] society and a feeling that is easier to carry out. With the web system it has also been able to break the assumption that the Quran memorizers do not know technology because they are focused on memorizing activities, this also certainly makes a big demand for Muslim scientists to be able to find / create a technology that can facilitate $\mathrm{Al}-$ Quran in memorizing it. 


\section{CONCLUSION}

Ha'iah Tahfizh Al-Qur'an (HTQ) is a semi-autonomous institution in the Maulana Malik Ibrahim Malang State Islamic University which focuses on memorizing Quran students and has used the technology in the form of web to facilitate all forms of adversity implemented. The web is used in a variety of Quran memorization activities ranging from student enrollment announcements, notification of selection test schedules, announcement of the results of completion tests, distribution of Quran memorization groups, final memorization tests, and appreciation activities to students who have mastered Quran memorization. With the use of the web, the management of Quran memorization is made easier so that students can access various activities related to memorizing the Quran wherever they are.

\section{ACKNOWLEDGEMENT}

Thank you to the UIN Sunan Gunung Djati LPPM Bandung who has been a sponsor in this research and also to the parties involved in the Maulana Malik Ibrahim State Islamic University Malang Indonesia.

\section{REFERENCES}

[1] H. Campbell, "Religion and the Internet," Oxford Handb. Sociol. Relig., vol. 25, no. 1, pp. 1-44, 2009.

[2] A. M. Zedan, M. Y. Z. B. M. Yusoff, and M. R. Bin Mohamed, "An Innovative Teaching Method in Islamic Studies: The Use of PowerPoint in University of Malaya as Case Study," Procedia - Soc. Behav. Sci., vol. 182, pp. 543-549, 2015. https://doi.org/10.1016/j.sbspro.2015.04.776

[3] A. N. Hidayat, "E-Learning Implementation in Islamic Education Innovation," HUNAFA J. Stud. Islam., vol. 14, no. 1, p. 17, 2017. https://doi.org/10.24239/jsi.v14i1.460.17-36

[4] W. B. Drees, "Technology, Trust, and Religion of Life Edited by," Religion.

[5] A. Y. Usman, "Using Information and Communication Technology (ICT) to Enhance the Teaching and Learning of Arabic and Islamic Studies in Nigeria," $J$. Teach. Educ., vol. 2, no. 3, pp. 353-368, 2013.

[6] T. Ebrahimifar, "Impact of Technology on Education in Islamic Countries in Middle East in the Political Communication Era," vol. 6, no. 1, pp. 1-17, 2017.

[7] B. Taufiq and A. Nugroho, "Integration of Islamic education with science and technology in Islamic junior high school," pp. 1-27, 2017.

[8] M. A. Lubis, M. M. Yunus, M. A. Embi, S. Sulaiman, and Z. Mahamod, "Systematic steps in teaching and learning Islamic Education in the classroom," Procedia - Soc. Behav. Sci., vol. 7, no. 2, pp. 665-670, 2010. https://doi.org/10.1016/j.sbspro.2010.10.090

[9] Muhammad Syukri Salleh, "Strategizing islamic education," Int. J. Educ. Res., vol. 1, no. 6, pp. 1-14, 2013.
[10] M. B. Aarayesh and A. Mansouri, "A Comparative Study of Present Situation and Desirable Plan in Performing of Educational Course in Universities Program of Training for the Staves in Islamic Azad University," Procedia - Soc. Behav. Sci., vol. 205, no. May, pp. 614-622, 2015.

[11] C. A. Llorente, J. O. Ang, K. R. O. Chan Shio, J. E. O. Chua, and E. I. C. Cu, "Implementation of a web based weather monitoring station and data storage system," Int. J. Adv. Trends Comput. Sci. Eng., vol. 8, no. 3, pp. 527-530, 2019. https://doi.org/10.30534/ijatcse/2019/29832019

[12] B. Saravana Balaji, R. S. Rajkumar, and B. F. Ibrahim, "Service profile based ontological system for selection and ranking of business process web services," Int. J. Adv. Trends Comput. Sci. Eng., vol. 8, no. 1, pp. 18-22, 2019. https://doi.org/10.30534/ijatcse/2019/04812019

[13] A. Kumar, K. kiran, D. Reddy, and S. Manikonda, "Design And Analysis Of High Speed, Low Power And Area Efficientdct Architecture For Multimedia Applicationsimplemented Oncadence 180nm," Int. J. Eng. Comput. Sci., 2016.

[14] N. Herzfeld, "Introduction: Religion and the New Technologies," Religions, vol. 8, no. 7, p. 129, 2017. https://doi.org/10.3390/rel8070129

[15] M. A. Ramdhani, D. Sa' adillah Maylawati, A. S. Amin, and H. Aulawi, "Requirements Elicitation in Software Engineering," Int. J. Eng. Technol., 2018.

[16] R. S. Pressman, Software Engineering: A Practitioner's Approach, 7th ed. New York: McGraw-Hill, 2011.

[17] I. Sommerville, Software Engineering. 2010.

[18] K. Laeheem, "Relationships between Islamic ethical behavior and Islamic factors among Muslim youths in the three southern border provinces of Thailand," Kasetsart J. Soc. Sci., vol. 39, no. 2, pp. 305-311, 2018. https://doi.org/10.1016/j.kjss.2018.03.005

[19] E. A. K. Farahani and A. salehi, "Development Model of Islamic Citizenship Education," Procedia - Soc. Behav. Sci., vol. 89, pp. 64-68, 2013. https://doi.org/10.1016/j.sbspro.2013.08.810 